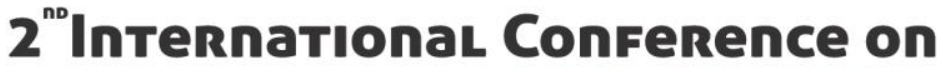 RESEARCH IN HUMANITIES
}

22 - 24 November, 2019 - Paris, France

\section{Victorian Masculinity in George Eliot's the Mill on the Floss}

\author{
Yoon Jung Cho' Il-Yeong Kim² \\ Sungkyunkwan University
}

\begin{abstract}
Many critics have examined George Eliot's The Mill on the Floss in terms of feminism, focusing on the patriarchal society's oppression on Maggie, the protagonist of the book. The oppression of the patriarchal society, however, is not confined to its female protagonist, since Tom Tulliver, Maggie's brother, is also the victim of the patriarchal society which is characterized by the rigid categorization of gender. Focusing on Tom who is led to sacrifice his own desire, this study aims to reveal the violence of Victorian patriarchal ideology, exploring the ideology of Victorian gentleman as an ideal masculinity. The Victorian masculinity which is constructed by the patriarchal society is forced on Tom who unwittingly and unconsciously imbibes its ideology from the school and home, the ideological state apparatus suggested by Louis Althusser. So Tom accepts the ideology of masculinity without any resistance and internalizes it as part of his identity. Such a circumstance, however, is not peculiar to Tom himself. It is the fate of all who should be in ideology to have his identity approved by the society.
\end{abstract}

Keywords:19C English Novel, Gentleman, Louis Althusser, Patriarchal System, Psychoanalysis. 